\title{
Partying and Cocooning? No Paradox for Mayoral Recruitment in Belgium
}

\author{
Kristof Steyvers, Herwig ReynaERT, Thomas Block \& TOM Verhelst
}

\begin{abstract}
This paper studies the role of partisanship in the road to the Belgian mayoralty. It confirms the expectation that most mayors have quite extensive party records prior to coming to office. Although different degrees of partisanship are thus relative, they tend to sort both internal and external effects. Mayors with a highly partisan background give a more active interpretation of their initial recruitment and get a head start in their political career. They also more frequently come from families that are deeply engaged in politics. In addition, they combine their own partisan experience with additional recruitment apprenticeships. Having held a function in a party and having experienced extensive party support make mayoral orientations more partisan in terms of task importance and exchange of views with party leaders.
\end{abstract}

KEYWORDS: • local government $\bullet$ mayor $\bullet$ mayoral recruitment $\bullet$ local party system $\bullet$ Belgium

Correspondence AdDress: Kristof Steyvers, Centre for Local Politics, Department of Political Science, Ghent University, Universiteitstraat 8, 9000 Ghent, Belgium, email: kristof.steyvers@ugent.be. Herwig Reynaert, Centre for Local Politics, Department of Political Science, Ghent University, Universiteitstraat 8, 9000 Ghent, Belgium, email: herwig.reynaert@ugent.be. Thomas Block, Centre for Local Politics, Department of Political Science, Ghent University, Universiteitstraat 8, 9000 Ghent, Belgium, email: thomas.block@ugent.be. Tom Verhelst, Centre for Local Politics, Department of Political Science, Ghent University, Universiteitstraat 8, 9000 Ghent, Belgium, email: tom.verhelst@ugent.be. 
In many contemporary democracies, parties and politics have almost become synonyms because the former operate a range of crucial functions for the latter. In mediating between civil society and government, parties aggregate and articulate interests for collective goal formulation. While such functions are programmatic, others are more societal, providing the agency with political learning and participation and mobilisation devices. Parties also contribute to state governability by forming, sustaining and facilitating government (Sartori, 1976; Ware, 1996). Currently, however, parties are going through a well-documented era of functional transformation ranging from partisan dealignment over the convergence to catch-all or electoral-professional party machines to a gradual cartelization with the state (Katz \& Mair, 1995; Luther \& Müller-Rommel, 2005).

This paper turns to one of these crucial but shifting party functions in studying elite recruitment for public office. To be more precise, the role of parties in recruitment is studied at a specific governmental level (local), and for a specific function (mayor) in a specific context (Belgium). By contextualising the role of the parties in Belgian local government, and by outlining the office of mayor, the importance of parties in political recruitment is subsequently scrutinized in the theoretical part of the paper. The empirical part combines insights from two datasets on Belgian mayors. First, we focus on the proliferation of party experience in mayoral recruitment. Second, party recruitment effects are sought both internally (career start and development, partisan centrality) and externally (aspects of local political leadership).

\section{Janus in the Belgian Hybrid Local Party System?}

Despite their increasing colonisation of governmental institutions at most levels, parties have been almost an extraneous body in many polities for a long time. A non-political or at least non-partisan conception of local government has always contributed to this feeling. In this conception, local self-government was seen as dedicated to the politically neutral common good of the local community. It called for singular, rational, and technical solutions in public service in which partisanship could only distract from the core of the issues (Fallend et al., 2006). It was only from the 1970s onwards that local party politicisation increased as a response to sharpening the public debate stemming from deeper societal, economic, and ecological transformations (Copus, 2004). This partisan reappraisal has often been interpreted in terms of nationalisation with the parties active at the centre level also incrementally acclaiming its local counterpart. In many municipalities, the local branches of national parties have become the leading forces in a partisan government. Still, the implicit equation with non-partisanship (at least in national terms) has not entirely left the local scene and the remaining importance of various local lists is illustrative in that sense. Moreover, students of 
local party politics have observed a shrinking relevance of party politics not in the least due to the growing dominance of governance-like decision-making over representative institutions populated by party politicians (Hoffmann-Martinot, 1998).

The Belgian local party system needs to be based on this equilibrium as well. Although the research on the broader embedding of parties in the local political system has been rather scarce, their importance in the electoral process is well documented (Buelens, Rihoux and Deschouwer, 2008). Particularly after the municipal amalgamations in 1976, Belgian local elections could be characterised as highly party politicised even in national terms (Dewachter, 1994). Up to the 1970s, local lists were the dominant political force in many municipalities. On average, more than two thirds of all local elections have been predominantly or even exclusively nationalized since 1976. Today, local branches of national political parties gain approximately $80 \%$ of all votes, and they often exclusively make up the partnership in the case of coalition government (Steyvers and Reynaert, 2006).

Some important qualifications should be added to this rather rough shift (based on the nominal criterion of national labels). Genuine national control and homogeneity might vary there where local branches of national parties dominate (Deschouwer, 1996). Moreover, local lists still seem to give a distinct place-bound touch to the electoral process in many municipalities. Local lists have been present in elections in approximately $75 \%$ of all the municipalities since 1976 . Yet, the local label flag seems to cover a highly varied loading. In addition to genuine local phenomena, it also covers pseudo-local initiatives (cartels of national parties with a local name, lists named after popular mayors who have clear national party affiliations). Nevertheless, these lists tend to proliferate in small-sized municipalities, and thereby going with a distinct profile in terms of organisation, political style, and policies, which suggests a partisanship light (Steyvers et. al, 2007). Thus, partisanship tends to be a structural and underlying force in local politics where the system is hybrid in terms of nationalisation.

\section{Doorkeepers of Public Office? Parties and Local Political Recruitment}

Literature suggests that the parties at the local level, apart from their double-faced appearance, resemble the Roman god Janus in yet another way of being the crucial doorkeepers in political recruitment, the '...process by which individuals are selected for inclusion among political elites' (Brady, Schlozman \& Verba, 1999: 153) currently colluded with (candidacy for) elections. Parties tend to play an important role both in the supply of eligible candidates and in the demand for eventual candidates (Norris, 1997). Regarding the latter, two central questions seem important: Who selects? What do these selectors look for? 
The complex interaction of several actors on the demand side and their reluctance to give an insight into this 'secret garden of politics' (Gallagher and Marsh, 1988) make the answer to the first question less straightforward. Yet, research has traditionally identified parties to be among the core actors when it comes to certification (social screening and political channelling of aspirations) and eventual selection of candidates (Seligman, 1961; Brand, 1972). This is also reflected in the self-proclaimed recruitment history of many councillors (Prewitt, 1970; Brady, Schlozman \& Verba, 1999).

Yet parties are not monolithic actors where all members are equally and univocally involved in recruitment. Also, subgroups emerge at the local level (rivalling). They engage deeply in candidate selection. As Hunt and Pendley (1972) have shown in their seminal study, local recruiters belong to the 'grey eminence' of the partisan scene. These community gatekeepers tend to combine the narrower involvement in the political sphere with the broader civic engagement by using their status to exert an indirect influence. Local party leaders often take the central position in these groups. Although they might be predominant, these party subgroups have no monopoly on recruitment. Support groups often take up sponsorship to promote certain candidacies (Seligman, 1971).

What are these selectors looking for? The research carried out by Brady and his colleagues (1999) suggests that they are looking for something familiar. Since politically relevant features are not always apparent to the naked eye of the recruiter, the latter uses informational shortcuts to identify (and mobilise) potential targets. This explains to the authors why recruiters so often fish in the pond of their own social and particularly partisan networks and (thus) reinforce a somewhat self-mimic type of candidate selection. When it comes to candidates, many see activities and networking in party organisations or the broader political sphere as crucial to the acceptance of their candidacy (Irwin, 1976). Other insights (Bochel and Denver, 1983) suggest that monitoring by recruiters is not strictly partisan though. Selectors logically value candidates that have electoral potential. To this end, subjective personal characteristics (e.g., communication skills) tend to serve more than strictly political ones (e.g., loyalty to party ideology). The extension of Hunt and Pendley's research on actual recruitment criteria is in line with the latter.

Parties also seem to play an important role on the supply-side of recruitment where future politicians acquire political capital and become motivated to strive for public office. Literature often places them within the broader involvement in civil society of many later political recruits. Local associations, in particular those close to the political sphere, are considered as the highway to the community power structure. They socialise members by providing collective solidarity for a common goal, serve as apprenticeships for governing, allowing the development 
of valuable networks (Balme, 1986). At the same time, they enhance the visibility of potential candidates for office for both selectors and the public (notoriety). Many future councillors identify involvement in civic organisations as an important gateway to their eventual recruitment (see Moss \& Parker, 1967). Without any doubt, parties belong to the core of this organised community life, and many future politicians have held membership and/or active governing functions in their ranks.

While such insights refer to recruitment in general, this paper focuses on leadership selection for the office of mayor in the Belgian local government context. Before coming to a more specific analysis of the latter subject, it is therefore necessary to outline the appointment and the position of the mayoralty in this local political system.

\section{From Central Agent to Local Principal. Mayors in Belgian Local Government}

While the Franco tradition in central-local relations has often been identified as one of the central historical features of Belgian local government (Steyvers, $2007)^{1}$, the office of mayor is usually in the collegiate tradition of an intergovernmental organisation in which layman primacy results in a monistic and collective conceptions of the executive formed by the college of mayor and aldermen (Mouritzen and Svara, 2002). While the latter are elected by the council, the former is appointed by the central government, though today in formal terms only. The mayoral function has undergone substantial evolutions.

Shortly after Belgian independence, the electoral and functional conditions for the mayoralty had already become the focus of fierce political discussion because of the introduction of the first Municipal Act in 1836. The conservatives opted for the central appointment of the mayor, which aimed to place a tutorial agent in the heart of the municipalities of the time. The pressure from the Liberals led to a compromise: the King should appoint the mayor from among the elected members of the local council. At that time, however, mayors had little to no local competences and very few official tasks to fulfil (Ackaert, 2005). They acted primarily as agents of their central principals. The mayoral function has gradually become more localised.

Since the adoption of the New Municipal Act in 1989, the central appointment has only survived in a largely symbolic fashion. The local council still provides the gateway to the function because mayors are appointed from among its Belgian members for the six-year period of the concurrent legislature. Nonetheless, an important political criterion has now been added to these formal requirements. Only the council members can propose a candidate for mayor ${ }^{2}$. In practice, the assignment of the mayoral position is thus subject to the bargaining process that is 
associated with the formation of governmental majorities. The largest party often gains the office, while the number of preferential votes collected by certain candidates plays a predominant role in assigning mayoralty to a specific individual (Steyvers, 2004). In nearly all cases, the central government appoints the candidate proposed by the council. This pseudo-appointment system has been fiercely debated regarding the possibility of a direct election of mayors (Steyvers et al., 2006).

A similar tendency can also be observed with regard to the content of the mayoral function. Formally, the mayor has always had a dual mandate, which involves central and local competences. However, central competences have been reduced to the level of merely symbolic and highly fragmented tasks. Local competences have gained ground by placing the mayor in a pivotal governmental position, even far beyond formal regulations. In general, mayors are key figures in the political institutions of local government. They head the council, keep in touch with related governmental layers, and act as the formal political figurehead responsible for the local administration, particularly concerning local policing and security policy.

The political significance of the mayoral functions goes far beyond the formal competencies that are now predominantly locally anchored, but still limited. It has undoubtedly become the single most important local political office (Ackaert, 2005). In terms of the role and task orientation, mayors identify themselves with municipal policy-making and government by developing a vision for their locality and by encouraging new projects for which they actively lobby. At the same time, mayors have become the trustees of their citizenry. Many mayors consider helping citizens with (governmental) problems to be an important part of their job. In addition, they take up ceremonial and representational tasks for the municipality. Finally, mayors also act as the political leaders of their majority and party (Steyvers \& Reynaert, 2005).

\section{The Partisan Recruitment of Mayors in Belgium? Research Questions and Data}

The gradual (national) party-politicisation of Belgian local elections, the central role of partisan actors in recruitment, the predominant valuation of party criteria in candidate selection combined with the incremental localisation, and party politicisation of the mayoral function contribute to the expectations that mayors follow a highly partisan and politically agglutinated pathway to power. The specific evidence that supports these assumptions is rather indirect or relatively old. It shows that parties play first violin in composing local electoral lists. The leading party actors engage in the candidate screening process that is often under the influence of interest groups and approved by the broader realm of party activists (Buelens, 1996). Regarding the specific pathway to executive functions in this context, parties again show up when the distribution of these mandates comes 
to the fore as part of majority formation. Party branches are consulted in a large majority of cases. The latter tend to value the number of preferential votes, and the governmental ability and experience are perceived as the most important criteria in (party) political life (Ackaert, 1996). Previous research on councillors (Devos et al., 1997) showed that almost two out of every three councillors was a member of a political party before attaining their office for the first time. Half of them displayed some activity in the party, while one third also exercised a function in the governing bodies of the (local) party.

While such insights hint at a partisan road to the mayoralty, this paper aims to present more direct, encompassing and up-to-date evidence of the importance of the national political party involvement in achieving mayoral office. Our analysis serves both descriptive and explanatory ends. Firstly, it assesses more generally the political capital mayors might have collected in parties during their recruitment process. To what extent are mayors elected from the lists of candidates with ties to national politics? Does their history of political activism before becoming a mayor reflect involvement in political parties and to what extent? What factors might give grounds for variation in this pattern?

Secondly, the paper pays attention to the potential effects of such a partisan path in recruitment. Internally, it focuses on the career start and development towards the mayoralty. Externally, it studies the effects of partisan recruitment on aspects of mayoral leadership. Does a partisan recruitment influence the priorities, time distribution or conceptions of democracy, and local governance once in office?

This paper draws on two quantitative datasets. The first one results from a postal survey conducted in 2002. It focused on the recruitment process of Belgian mayors $(\mathrm{N}=379)$. Here, the response was high $(64.3 \%)$. Data were representative of region, number of inhabitants, and partisan background (Steyvers, 2004). The second one stems from the international research project 'Political Leaders in European Cities', a comparative assessment of mayoral leadership in 16 European countries. It deals with the municipalities of over 10000 inhabitants (Bäck, Heinelt and Magnier, 2006). For Belgium, the authors conducted research in 2003. They also included the mayors of small municipalities $(\mathrm{N}=242)$. Here, the response was a bit lower $(41.1 \%)$, but still representative of the variables mentioned. Both datasets refer to the mayoral legislature 2000-2006. For most questions, the focus of the study was the first mandate as mayor. There were two standardised questionnaires. For the most part, they used closed questions.

This approach needs two important interpretative qualifications. First, it studies a process by its outcomes because our respondents have effectively achieved their mayoralty. Moreover, studying variation in this group may overemphasise heterogeneity in a group that actually shares many characteristics. Second, since the mayors themselves replied to the questionnaires, we should speak of a 
subjective reconstruction of recruitment experiences rather than of an objective account of party importance in candidate selection. However, the factual nature of a number of elements under study provides a counterweight to an all-too subjective and hence inconclusive account of this process.

6

\section{Proliferation of Partisanship in the Recruitment History of Belgian Mayors}

To what extent does partisanship colour the recruitment history of Belgian mayors? We can start to answer this question by using our 2002 dataset and focusing on both attitudinal and behavioural descriptive components of partisanship. Table 1 presents some indicators, reflecting the preference for a national political party, and the activity within the ranks of (youth branches of) political parties. Incumbents were asked to reflect on the period prior to their first mandate as mayor.

\section{Table 1: Partisanship indicators among Belgian mayors}

\begin{tabular}{|l|c|c|}
\hline Partisanship & \% & N \\
\hline Political preference & & \\
Present & 89.4 & 334 \\
Nature & & \\
Christian democrat & 43.6 & 146 \\
Liberal & 26.0 & 87 \\
Socialist & 25.0 & 84 \\
Other & 5.4 & 18 \\
\hline Party youth branch & & \\
Member & 41.4 & 156 \\
Function & 27.0 & 102 \\
President & 57.6 & 57 \\
Other & 42.4 & 42 \\
\hline Party & & \\
Member & 90.5 & 343 \\
Active & 81.5 & 309 \\
Function & 62.3 & 235 \\
President & 41.7 & 93 \\
Vice-president & 11.7 & 26 \\
Secretary & 16.6 & 37 \\
Other & 30.0 & 67 \\
\hline
\end{tabular}

As the table shows, the large majority of Belgian mayors (almost $90 \%$ ) have a clear preference for a national political party in the period prior to their first mayoralty. Christian democrats are most popular, while liberals and socialists (each of them) represent one quarter of mayoral preferences. As the Christian democrats are considered to be the most centrist among the traditional parties, it should not surprise us that when mayors were asked to place themselves on the 
left-right scale, the average value was $5.0(\mathrm{~s}=1.7)$. This observation holds even if approximately $30 \%$ of all the mayors indicate that they were elected on a local list (i.e., not bearing any national name or number) in the election leading them to their first mandate as mayor. These partisan orientations tend to be translated into subsequent behaviour, although less from the early life phases of the future mayor (youth branches of political parties), but outspokenly in the further development of his career.

Mere membership is similar to the proliferation and distribution of party preferences. At least the more passive apprenticeship in the ranks of a party tends to be an unavoidable asset for mayoral recruitment. The latter goes well beyond the symbolic token of a party membership card. On average, this group of respondents held party membership for 18.5 years $(s=9.3)$ prior to their first mandate as mayor. Yet partisan involvement went further than an enduring membership. More than $80 \%$ of all mayors were also active in their party by offering assistance in electoral campaigns, and by attending party meetings on a regular basis. A large majority of mayors (almost two-thirds) also exercised a party function in the period before their first mandate. Beyond the proverbial coffee-making, the largest group of respondents who were party officials functioned as a president ${ }^{3}$. If the three most important party functions are considered (president, vice-president, and secretary), 70\% of this group is covered. On average, this function was exercised for 8.4 years $(\mathrm{s}=6.4)$ before becoming mayor. In almost three-quarters of all cases, the party function was exercised at the local level. This suggests that future mayors have extensive roots in the local party organisation they have often governed.

Youth branches of political parties can be a fruitful environment for the breeding of political talent and partisan socialisation. As our data show, they seem to be a less unavoidable road to be taken when it comes to mayoral recruitment. Still, a large number of our respondents were members of these youth branches, and more than a quarter of them even exercised a function in it. Again, the position of President was most popular among these office holders. In the majority of cases, the function was exercised at the local level.

What happens if we consider these partisanship indicators together? Is partisanship cumulative? Could we hence index it with varying degrees of importance as a recruitment factor? Considering the dummied presence of a political preference, membership, (activism) and exercising a function in a (youth branch of a) political party do not allow genuine scaling based on factor analysis ${ }^{4}$. Yet there are good theoretical reasons to assume that the somewhat reverse cumulative nature of partisanship with those active in the more intense dimensions are likely to have less demanding indicators of involvement in their party track record. The correlation matrix of the variables under study ${ }^{5}$ supports this assumption. Therefore, we created a count variable from the affirmative answers 
to the dummies mentioned. The histogram displayed in graph 1 illustrates this partisanship index. The index scores vary between 0 and 6 , given the indicators under study ${ }^{6}$.

\section{Graph 1: Partisanship index among Belgian mayors}

\section{Partisanship index}

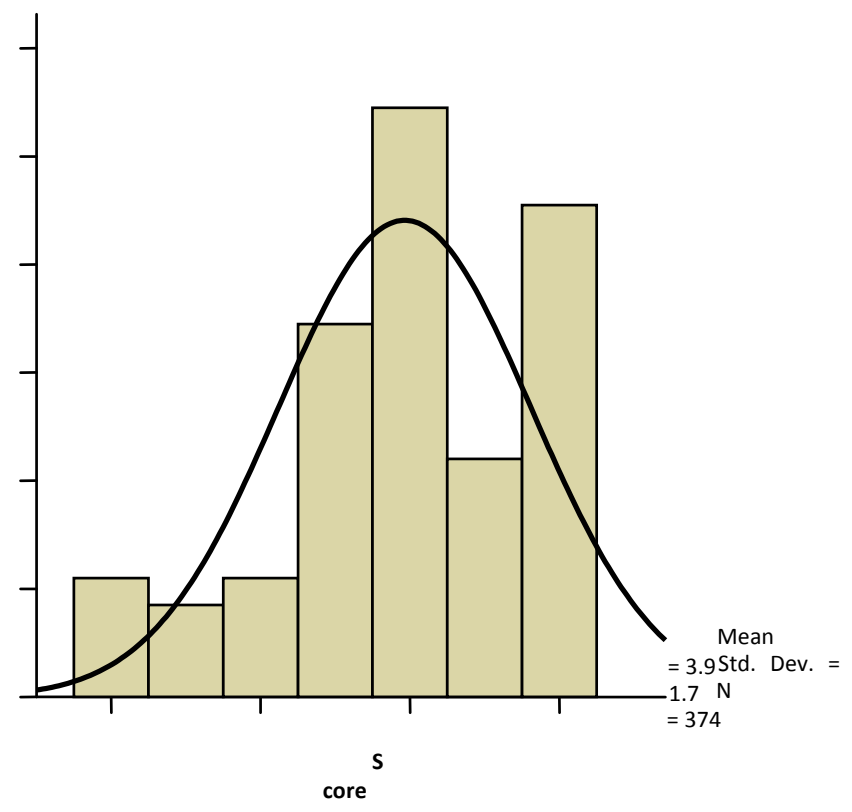

Generally speaking, the graph confirms that most respondents have quite extensive party records before attaining the mayoralty. Hence, only $6 \%$ of all the mayors could be termed as entirely non-partisan, and $65 \%$ of them are to be above the scale mid-point. Further analysis shows that it is especially the indenture at a relatively young age in the ranks of the party youth branch that sets apart the most partisan recruitment path from the lesser one. So, when considering party recruitment as a continuum, it should be kept in mind that it is relative, i.e., the bulk of all mayors do have some (and many quite a few) partisan marks on their pathway to office.

If such variation exists, what factors might account for it? Given the non-normal distribution of our index ${ }^{7}$, logistic regression might help us out. As a dependent variable, the index of partisanship was transformed into a dummy with a value of 
1 referring to high scores (i.e. 5 or more $)^{8}$. A number of factors were considered as independent variables that were assumed to have an impact on partisanship. Some factors refer to the broad municipal environment of mayoral recruitment. We know from previous research (Steyvers et al., 2007) that the nationalisation of the party system tends to be most outspoken in the Flemish region of Belgium. We can expect that this would lead to more partisan recruitment reflected in extensive records of accomplishment in political parties. The same holds true for urbanisation. In high-density environments, electoral competition is more outspoken and often translated into national terms (Dewachter, 1994) .

Other factors are more closely linked to the mayoral recruitment itself. In addition to the factor indicating that the mayor was elected on a national list, Garraud's (1989) assumptions of the left-wing tradition and the time-bound increase in partisan recruitment were analysed. As Garraud expected the latter to become the standardised core routes into office after the 1990s, the respondents who took up mayoral office for the first time following the elections of 1994 or later were set apart from their counterparts who had taken office earlier. Multicollinearity did not reach any critical values. Table 2 represents the results of this logistic regression analysis. Data refer to odds ratios and significance ${ }^{10}$. Nagelkerke $\mathrm{R}^{2}$ reflects the overall explanatory power of the model.

Table 2: Partisanship index among Belgian mayors. A logistic regression analysis

\begin{tabular}{|l|c|c|}
\hline & \multicolumn{2}{|c|}{ Partisanship Index (high) } \\
\hline Factor & $\operatorname{Exp}(\boldsymbol{B})$ & Sign \\
\hline $\begin{array}{l}\text { Region } \\
\text { Flanders }\end{array}$ & 2.47 & .002 \\
\hline $\begin{array}{l}\text { Urbanisation } \\
\text { High-density population }\end{array}$ & 1.12 & .677 \\
\hline List & & \\
$\quad$ National & 3.61 & .000 \\
$\quad$ Socialist & 1.08 & .816 \\
\hline Era of entry & & .355 \\
$\quad$ First mayoralty $[>1994]$ & 1.28 & $\mathbf{. 0 0 0}$ \\
\hline Nagelkerke R & $\mathbf{. 1 8}$ & \\
\hline
\end{tabular}

$\mathrm{N}=346$

The overall model is highly significant, but moderately strong at predicting whether mayors belong to the highest category of party recruitment. Not all factors are significant or equally important though. An environmental factor and an electoral one can account for variation. A mayor from the northern region of Flanders has significantly more chances to have the most extensive record of party accomplishments (mean index score $=4.3$ against 3.4). The same holds true for the respondents who were elected on a list with clear national references, though 
the effect of this variable was much larger than that of the region (mean index score $=4.7$ against 2.9). Contrary to our expectations, urbanisation and age of entry had no significant predictive power of partisanship when considered together with the other variables mentioned.

\section{Parcel of Political Cocooning? The Internal Effect of Partisan Recruitment}

The recruitment history of our mayors thus tends to be highly partisan in several respects. While such a picture stands out for the Belgian mayor in general, we have found some variation in partisanship among them. Here we want to take the analysis one step further by scrutinizing the potential effect of differences in partisan recruitment. In this section, we study its internal effects on other dimensions and aspects of recruitment. Firstly, we focus on the effect of variation in partisanship on the career start and development of our respondents. Secondly, we take into consideration some alternative routes to the mayoralty, and we study the extent to which they serve as functional equivalents or as additions to partisan recruitment. Since our dataset is richest in partisan experiences in the mayor's background, the analysis of internal effect will focus on this dimension.

\subsection{Career Start and Development}

Does variation in partisan recruitment change the modes through which future mayors enter politics, the motives they attribute to their first candidacy, and the moments important to career development? Table 3 gives some answers to these questions. As an indicator of partisanship, the previously developed index is dichotomised into higher and lower strata ${ }^{11}$. Data refer either to the percentage of mayors observed in each category or to the mean value of the characteristic under study.

Table 3: Modes, motives and moments of recruitment according to partisanship

\begin{tabular}{|l|c|c|c|c|c|c|}
\hline & \multicolumn{5}{c|}{ Partisanship Index } \\
\hline \multicolumn{1}{|c|}{ Career } & \multicolumn{2}{|c|}{ Low } & \multicolumn{2}{c|}{ High } & \multicolumn{2}{c|}{ General } \\
\hline Modes & \%/mean & $\boldsymbol{N}$ & \%/mean & $\boldsymbol{N}$ & \%/mean & $\boldsymbol{N}$ \\
Self-starter & & & & & & \\
Drafted & 27.9 & 58 & 36.3 & 41 & 30.8 & 99 \\
Mediated & 51.9 & 108 & 29.2 & 33 & 43.9 & 141 \\
Other & 17.3 & 36 & 33.6 & 38 & 23.1 & 74 \\
\hline Motives & 2.9 & 6 & 0.9 & 1 & 2.2 & 7 \\
Civic duty & & & & & & \\
Party duty & 37.9 & 91 & 29.5 & 39 & 36.0 & 130 \\
Policy plans & 10.0 & 23 & 16.7 & 22 & 12.5 & 45 \\
& 10.9 & 25 & 11.4 & 15 & 11.1 & 40 \\
\hline
\end{tabular}




\begin{tabular}{|l|l|l|l|l|l|l|}
\hline $\begin{array}{l}\text { Job/career } \\
\text { opportunity } \\
\text { Change/renewal }\end{array}$ & 12.2 & 28 & 11.4 & 15 & 11.9 & 43 \\
$\quad \begin{array}{l}\text { Other } \\
\text { Moments }\end{array}$ & 14.8 & 34 & 14.4 & 19 & 14.7 & 53 \\
$\quad$ Party member & 28.5 & 191 & 22.4 & 125 & 26.1 & 316 \\
Candidate & 35.0 & 230 & 29.7 & 130 & 33.1 & 360 \\
Elected & 35.6 & 230 & 30.6 & 130 & 33.8 & 360 \\
Mayor & 46.3 & 229 & 40.9 & 128 & 44.4 & 357 \\
\hline
\end{tabular}

Mayors were asked to reflect on the way in which they initially were exposed to local politics. A recoding of the initial alternatives, among which mayors had to select the one that was deemed most important, showed significant differences according to partisanship ${ }^{12}$. The respondents with the highest level of partisanship more frequently referred to their own initiative, interest or conviction, and to mediation by specific persons (family, friends, and acquaintances) or associations to the detriment of being asked (the drafted) as their initial mode of political recruitment. Of course, these alternatives are not mutually exclusive in terms of substance. Yet in our opinion, they refer to different logic of interpretation of the early stages of recruitment. Especially the drafted tend to a more passive model of inclusion among the political elites that need an external push of an explicit demand to overcome the last threshold of effective recruitment. Highly partisan mayors tend to give a more active interpretation of initial recruitment.

If modes are different, then are motives too? The answers to an open-ended question about the most important motive for the future mayor to be a candidate on the electoral list for the first time are recoded in the categories displayed in the table. However, they reveal no significant differences in cross-tabulations according to partisanship ${ }^{13}$. Yet some tendencies appear. While there is some kind of civic duty that is most frequently mentioned as the most important motive for candidacy among all mayors, it is less outspoken so for the respondents with the highest levels of partisanship. The latter more often refer to a party duty or to the idea that their candidacy could bring about change, renewal or rejuvenation of local politics. There are some hints of notable recruitment and taking a distance from politics among those with lower levels of partisanship. Giving in to an explicit recruitment request is seen as a duty for the local citizenry rather than a deliberate effort to engage in local party politics.

At a significantly later age, such an engagement tends to occur among the future mayors from the lower partisan strata. This holds true for the age at which our respondents became members of a political party, stood (successfully) for election for the first time, and eventually became mayor ${ }^{14}$. There is a notable and constant difference of approximately six years between both groups of mayors in each of these momentums. While highly partisan mayors thus engage at a significantly younger age, this confirms insights from previous research on the non- 
contractibility of political careers (Schlesinger, 1966; Hain, 1974). These data probably also reflect deep involvement in youth branches of political parties in the higher partisan strata.

\subsection{Alternative or Additional Apprenticeships?}

Political capital and motivation for recruitment may well be collected through other means than on a strictly partisan basis. Other factors might overwrite, compensate or add up to party experiences on the pathway to mayoralty. Do mayors acquire their political skills elsewhere? To what extent do these experiences operate as a functional equivalent to partisanship? Should they be considered as additions to the party recruitment model? Table 4 represents a number of such alternative apprenticeships. Data are cross-tabulated according to the partisanship index.

Table 4: Alternate apprenticeships in recruitment according to partisanship

\begin{tabular}{|l|c|c|c|c|c|c|}
\hline & \multicolumn{6}{|c|}{ Index of partisanship } \\
\hline & \multicolumn{2}{|c|}{ Low } & \multicolumn{2}{c|}{ High } & \multicolumn{2}{c|}{ General } \\
\hline Apprenticeship & \%/mean & $\boldsymbol{N}$ & \%/mean & $\boldsymbol{N}$ & \%/mean & $\boldsymbol{N}$ \\
\hline Social background & & & & & & \\
Male & 95.0 & 226 & 95.6 & 129 & 95.2 & 355 \\
University education & 40.9 & 97 & 53.0 & 71 & 45.3 & 168 \\
Brokerage profession & 59.1 & 140 & 55.2 & 74 & 57.7 & 214 \\
Local roots & 62.2 & 148 & 66.7 & 90 & 63.8 & 239 \\
\hline Political family & & & & & & \\
Political family index & 3.1 & 239 & 4.8 & 135 & 3.7 & 374 \\
\hline Political mandate & & & & & & \\
Experience & 79.5 & 190 & 88.9 & 120 & 82.9 & 310 \\
Local & 83.3 & 155 & 76.1 & 90 & 80.6 & 245 \\
\hline Associational life & & & & & & \\
Unions & 0.8 & 239 & 1.0 & 135 & 0.9 & 374 \\
Ideological & 0.4 & 239 & 0.8 & 135 & 0.6 & 374 \\
associations & 1.0 & 239 & 1.2 & 135 & 1.1 & 374 \\
$\quad$ Non-ideological & & & & & & \\
associations & \multicolumn{7}{|c|}{} & & & & \\
\hline
\end{tabular}

Coming from a privileged social background is often considered as an important base for political recruitment (Steyvers and Reynaert, 2006). The future mandate holders come from the higher social strata with substantial links to politics. Garraud (1989) has suggested that while social characteristics might be of importance for the recruitment of all mayors, partisanship could function as an alternative asset for individuals with a less favourable background. The indicators that are displayed in the table do not confirm such a distinction. Rather, a favourable social background tends to belong to the assets of every future mayor. 
There are no significant differences between the higher and lower partisan strata when it comes to gender, local roots (being born in the municipality) or coming from a brokerage profession. The latter refers to high status jobs that are complementary with politics because they often allow flexible time arrangements, professional independence, the development of politically useful networks, and that enhance coming into contact with the political sphere (Norris and Lovenduski, 1993). In our analysis, we categorised teachers, managers from private firms, higher civil servants, and people from the liberal professions (e.g., lawyer, doctor) under this heading ${ }^{15}$. This is the only favourable background characteristic more often found among the mayors from the lower partisan group though. The mayors from the higher partisan strata significantly more frequently have a university education ${ }^{16}$.

Coming from a political family could be a powerful asset to mayoral recruitment. Many future office holders tend to contract the political microbe at home quite literally becoming familiar with public issues and the customs of the political process (Lecomte, 1989). Sometimes, such an overexposure to political stimuli occurs along politically agglutinated lines with future recruits growing up with the example of a close relative that is a partisan militant or even an office holder. Especially in the latter cases, familial political notoriety might be an important advantage to the ambitious office prospect (Garraud, 1992). A substantial part of our questionnaire focused on the influence of familial actors on mayoral recruitment. Especially the parents of our respondents were studied.

The family politicisation index could be constructed from this analysis (Van Liefferinge and Steyvers, 2009). This PFI stems from two count variables. The first one refers to the extent to which respondents have a father who had an interest in politics, a clear political preference, was a member of an ideological association, a member of a political party, or he exercised a political mandate himself. This counting was replicated for the mother. Despite the fact that father politicisation data are predictably more outspoken than mother politicisation data, the scores on both count variables tend to covariate in a political family dimension producing a reliable $0-10 \mathrm{scale}^{17}$. The mean score on the latter is displayed in the table. Mayors from the higher partisan strata score significantly higher on this index than their counterparts ${ }^{18}$. Since its indicators tend to be cumulative, the deeply rooted partisan record of the future mayor seems to be mirrored by a similar party encapsulation of his close family with almost dynastic fringes.

It is often assumed that experience in other political mandate is the best proxy of eligibility and electoral success for any given mandate (Kjaer, 2006). As our description of the function has made clear, the mayoralty is among the most important mandates at the local level in Belgium. More experienced politicians can attain the mayoralty more easily than mere neophytes can. Our data confirm this. A large majority of mayors have had other elective mandate before becoming 
mayor for the first time. Yet, the differences between the lower and higher partisan strata are significant when it comes to the necessity for the previous career as a mayoral recruitment token ${ }^{19}$. The mayors with the highest partisan background tend to follow the core route into office, combining extensive party experience with a successful apprenticeship in the very heart of the political realm. Such a path suggests political cocooning of the future mayors who are gradually becoming encapsulated into institutionalized politics. While approximately $57 \%$ of all mayors combine both experiences, this figure rises to more than $85 \%$ when the highest partisan strata are considered.

Political careers tend to be locally anchored and gradually built up. The respondents were asked to indicate the mandate they had held and deemed most important prior to the first mayoralty. A large number of mayors referred to the mandate of councillor $(20 \%)$ and to the mandate of alderman $(57 \%)$ as most important before attaining their office. Successful experience in an executive mandate covers a number of policy domains and functions as a manifest office (Schlesinger, 1966) to the mayoralty. That the number of mayors from the higher partisan group referring to local offices is lower than among the lower partisan group is the result of more frequent parliamentary experience among the former.

Finally, the table displays a number of other associations that could function as equivalents to parties such as unions, other ideological associations or their nonideological counterparts (e.g., sports, culture or music). It represents means of the index scores for count variables covering membership, activism, and holding office in these associations. Regarding unions and non-ideological associations, the differences between the higher and lower partisan groups were not significant. This picture is different for ideological associations. Here mayors from the higher partisan strata show significantly more involvement ${ }^{20}$. Such associations can often be found in the periphery of party organisations. This has once again confirmed the general conclusion from the table that alternate recruitment assets should be considered as an addition rather than as a genuine alternative to a partisan pathway to office.

\section{Does Party Matter? The External Effect of Partisan Recruitment}

Partisanship tends to have an internal effect on recruitment. Could we extend this effect also to an external dimension? Does coming from a highly partisan background influence the way mayors actually understand and fulfil their mandate? While most of the literature has focussed on the effect of social background characteristics as recruitment features to explain role conceptions and behaviour in public (e.g., Edinger and Searing, 1967; Offerdal, 2003), others have included partisan experiences to explain variation in the functioning of the locally elected bodies such as the council. While Thurber (1976) and Fielin (1967) are more indirect in their seminal studies (by showing that the general party 
domination in a given constituency, and specific recruitment control tend to produce office holders that are highly partisan in their outlook and actions), Bäck has shown in a recent comparative analysis (2006) that party matters when considering the latter within a broader framework of mayoral loyalties. Not too surprisingly, party membership and perceived support from partisan actors especially matter for the mayoral tasks that are directly associated with parties.

The use of the extended Belgian data from the comparative set on which Bäck has drawn his conclusion allows us to broaden partisan orientation beyond task conceptions in a country-specific context ${ }^{21}$. The questionnaire enables us to study the effect of different (partisan recruitment) variables on a number of role dimensions that can be linked to the partisan orientation of mayors. For tasks, the importance attached to the party programme implementation is studied. Time refers to the proportion dedicated (on average) to political party meetings every week. The frequency of communication with the leaders of their own parties can tell us something about the contact patterns of mayors. Lastly, we scrutinized the agreement mayors expressed on the statement that political parties are the most suitable arena for citizen participation. Since none of the dependent variables were normally distributed, a logistic regression analysis was conducted on dummies of the originals with code 1 referring to the respondents scoring highest in terms of the initial values ${ }^{22}$.

As independent variables, various factors referring to dimensions of partisan recruitment were included to indicate the number of years respondents were party members, the extent to which they held party offices before becoming mayor, and the support they perceived from partisan actors during elections. These categories of variables thus link to both demand and supply factors of partisan recruitment. Two contextual counterparts were added to the direct partisan variables for which the analysis shows in table 2 that they have an impact on the partisanship level in mayoral recruitment, i.e., election on a list that is a local branch of a national party and attaining the mayoralty in a Flemish municipality ${ }^{23}$. Multicollinearity has not reached any critical values. Table 5 presents the analysis results. The data in the table refer to odds ratios and significance of any given relationship. Nagelkerke $\mathrm{R}^{2}$ summarizes the overall explanatory power of the model. 
Table 5: Dimensions of partisan orientation among Belgian mayors. A logistic regression analysis

\begin{tabular}{|c|c|c|c|c|c|c|c|c|}
\hline & \multicolumn{8}{|c|}{ Partisan orientation } \\
\hline & \multicolumn{2}{|c|}{$\begin{array}{c}\text { Task } \\
\text { [programme } \\
\text { implementation] }\end{array}$} & \multicolumn{2}{|c|}{$\begin{array}{c}\text { Time } \\
\text { [party meetings] }\end{array}$} & \multicolumn{2}{|c|}{$\begin{array}{c}\text { Communicatio } \\
\boldsymbol{n} \\
\text { [party leaders] }\end{array}$} & \multicolumn{2}{|c|}{$\begin{array}{c}\text { Participation } \\
{[\text { best mechanism] }}\end{array}$} \\
\hline & $\operatorname{Exp}(B)$ & Sign. & $\operatorname{Exp}(B)$ & Sign. & $\operatorname{Exp}(B)$ & Sign. & $\operatorname{Exp}(B)$ & Sign. \\
\hline $\begin{array}{l}\text { Partisan } \\
\text { recruitment } \\
\text { Member } \\
\text { [experienced] } \\
\text { Function } \\
\text { Support [high] }\end{array}$ & $\begin{array}{l}0.74 \\
0.78 \\
2.16\end{array}$ & $\begin{array}{l}.342 \\
.409 \\
.014\end{array}$ & $\begin{array}{l}0.65 \\
1.50 \\
1.55\end{array}$ & $\begin{array}{l}.183 \\
.192 \\
.160\end{array}$ & $\begin{array}{l}0.71 \\
2.48 \\
2.26\end{array}$ & $\begin{array}{l}.270 \\
.003 \\
.010\end{array}$ & $\begin{array}{l}0.96 \\
1.70 \\
1.65\end{array}$ & $\begin{array}{l}.879 \\
.080 \\
.105\end{array}$ \\
\hline $\begin{array}{l}\text { List } \\
\text { National }\end{array}$ & 1.12 & .765 & 1.17 & .705 & 0.43 & .048 & 1.54 & .274 \\
\hline $\begin{array}{l}\text { Region } \\
\text { Flanders }\end{array}$ & 1.22 & .503 & 1.30 & .388 & 1.06 & .850 & 1.62 & .106 \\
\hline 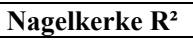 & .05 & .177 & .04 & .301 & .14 & .001 & .08 & .049 \\
\hline
\end{tabular}

$\mathrm{N}=194,197,201,199$

The model shows mixed results when it comes to explaining variation in different dimensions of mayoral partisan orientations. It cannot significantly predict the odds for mayors to be placed in higher categories of importance and proportions regarding the party programme implementation or the time spent in party meetings. The overall agreement on considering the party programme implementation as one of the mayor's most important tasks might help to understand why variation cannot be linked to partisan recruitment. Only partisan support produces a significant effect: the more a mayor perceived such support, the more importance he tends to attribute to implementing the party programme. For mayor's time management, a general reluctance to spend considerable amounts of time for party activities comes forward. This probably refers to a restrictive interpretation of such activities because contact with councillors or comembers of the College of Mayor and Aldermen can have a strong partisan dimension. Such activities might also lead to the limited importance of the party outside public office.

The model gains in explanatory power for communication and participation. Mayors with experience as party officials, and those who perceived much support from partisan actors have significantly higher chances of communicating with their own party leaders on a weekly basis or more frequently. There tends to be a profound and frequent exchange of views between the mayors whose recruitment is rooted in a partisan environment and the party leaders, which suggests extensive interdependence between them. Unexpectedly, the odds of the mayors elected on national lists (i.e. local branches of national parties) are lower when it comes to the frequency of contact with partisan leaders. While the overall model significantly explains variation in the extent to which mayors agree that parties are 
the most suitable arena for citizen participation, none of the single independent variables refers to odds that are significant. Having held a function in a political party before becoming mayor comes closest to a significant effect.

\section{Conclusion. Mayoral Recruitment between Partisan Standards and Cumulative Options}

This paper seems to confirm most assumptions about strong partisan mayoral recruitment that places Belgium in the higher strata of the partisan dimension Bäck (2006: 149) has identified as an important (but often neglected) factor in the comparative analysis of local leadership. With the local party politicisation of the office, mayoral recruitment came to the core of party functioning at the municipal level. As a result, most mayors have quite extensive party records before attaining the mayoralty. Therefore, variation in partisan recruitment is relative. Nearly all mayors seem to meet the lower partisan standards that tend to be unavoidable to attain the mayoralty (such as membership and activity in or support from party organisations and/or actors). For many, such standard equipment (or survival kit) is supplemented by more intense party involvement, frequently in the early stages of political life.

Stronger partisan involvement tends to produce both internal and external effects on mayoral recruitment. The respondents with a highly partisan background give a more active interpretation of their initial recruitment that begins at an earlier age, a head start carried along for the rest of the (pre)mayoral career. In addition, they frequently come from the families that are deeply engaged in politics, and they combine their own partisan experiences with additional recruitment assets such as other elective mandates and involvement in ideological associations. Rather than referring to alternate pathways to office, such a pattern points to a recruitment that is either taking place in a narrower and separate political sphere or not.

Party recruitment also seems to matter externally, but not in all aspects, always and/or to an even extent. Having held a function in a party, and, more frequently, having experienced extensive party support make mayoral orientation more partisan in terms of task importance and exchanging views with party leaders. This suggests that parties tend to be a kind of an internal perceptual screen operating in the back of our respondents' mind, especially with partisan support, regularly tuning mayoral waves of thinking and acting to a partisan frequency. Its amplitude is partially dependent on the extent to which partisan experiences colour the pathway to office.

With partisanship as a general characteristic of mayors, its extensive forms seem to produce recruits that are engaged in the narrower and institutionalized political sphere of society at an earlier stage in life, and tend to accumulate (valued) additional political capital within it. This political agglutination also turns loyalties 
to parties more strongly. The dramatic evocation of 'parties without partisans' should be modified for at least Belgian mayors (Dalton and Wattenberg, 2002). Parties keep a firm grip on the recruitment for one of the most important elected functions at the local level in Belgium. Such encapsulation might provoke tensions with general dealignment of parties that become isolated in public office with mayors coming to office and acting in it with a strong partisan frame of reference, and thus very different from the general citizenry. If such a division of political labour might come without clear mediation in an era where representation gives way to responsiveness (Rao, 2000), it could lead to a self-referential and autoreproductive recruitment that could stimulate a problematic gap between citizens and politicians. However, future research has to deal with this potential challenge to representative democracy.

\section{Notes}

${ }^{1}$ Characterized by rather low functional proliferation and discretion, communalism dominates over service delivery counterweighted by frequent and personalized access (through accumulation of political mandates) to the centre.

${ }^{2}$ To do so, a decree, which has been signed by the majority of all councillors (and those on the electoral list of the mayor), is necessary.

${ }^{3}$ The mayors who indicated to have been party officials were asked to select the function they exercised and considered as most import.

${ }^{4}$ Given such dummies would be pseudo-rational only.

${ }^{5}$ Correlation coefficients varied between .16 and .73 with all significant at the .002 level at least.

${ }^{6} \mathrm{~A}$ score of 6 means that the mayor had a clear preference for a political party, was a member, and had a function in the youth branch of his party, and was a member, activist, and office holder in his party.

${ }^{7}$ Kolgomorov-Smirnov $=.17$ with $\mathrm{p}=.000$.

${ }^{8}$ Frequencies for three equal groups showed the index scores of 5 and 6 to be high. They refer to $36.1 \%$ of all the valid cases. Purely theoretical, this dichotomy is probably not the best thinkable. The non-high group gathers mayors with no to little party experience of those who score up to 4 . However, given the distribution of partisanship, it is the only valid empirical solution.

9 Population density was chosen over mere numerosity. In 1976, amalgamations made it possible that a number of rural and sprawling municipalities could form a new administrative structure so that high population numbers could still refer to largely rural areas. A continuous variable of population density was divided into three equal groups with high $=403$ inhabitants/square kilometre or more, and $33.3 \%$ of all the cases.

${ }^{10}$ Since all independents are dummies, their effect on the dependent could be compared to one another. Enter procedure was used.

${ }^{11}$ High refers to values 5 and 6 in the index. Given the relatively limited total number of cases, a threefold categorisation showed to be less reliable empirically.

${ }^{12}$ Cramér's $\mathrm{V}=.25$ and $\mathrm{p}=.000$.

${ }^{13}$ Cramér's $\mathrm{V}=.14$ and $\mathrm{p}=.249$.

${ }^{14}$ For party membership, only effective members were taken into analysis. All means differed significantly at the $\mathrm{p}=.000$ level with Eta squares respectively $=.16$ (age party membership), .12 (age first candidacy at election), .10 (age first election) and .08 (age first mayoralty). 
15 Original question: 'what was your occupation before your first mandate as mayor'. The categorisation is slightly incomprehensive in the answers to the option 'other, please specify' a number of mayors stated to be professional politicians, a category well falling under 'talking and brokerage professions'.

${ }^{16}$ Cramér's $\mathrm{V}=.12$ and $\mathrm{p}=.025$.

${ }^{17}$ Principal component analysis for Father Politicisation Index $(0-5$; with $\mathrm{x}=2,3$ and $\mathrm{s}=1,5)$ and Mother Politicisation Index (0-5; with $\mathrm{x}=1,4$ and $\mathrm{s}=1,3)$ revealed an underlying component explaining $75,6 \%$ of variance. Reliability analysis produced a Cronbach's alfa of .70 .

${ }^{18}$ Eta squared $=.11$ and $\mathrm{p}=.000$.

${ }^{19}$ Cramér's $\mathrm{V}=.12$ and $\mathrm{p}=.021$.

${ }^{20}$ Eta squared $=.03$ with $\mathrm{p}=.001$.

${ }^{21}$ In addition to (partisan) loyalties, Bäck also studied the effect of group belonging and socialization, and learning. The analysis showed that party loyalties were explanatory more often than group belonging and socialization variables, but also support from local community actors mattered for mayoral task conceptions. Bäck used data for 17 countries with the 10000 inhabitant threshold. Here we will focus on Belgium only, but we will also include the mayors from the municipalities under 10000 inhabitants. See section 5 for more methodological background.

${ }^{22}$ For 'tasks', the original question was: 'many different tasks are associated with the mayor's position. How important do you think the following tasks are?'. Mayors could answer on a scale from 0 (not a task of the mayor) to 4 (of utmost importance). For the item 'to implement the programme of my political party/movement' $\mathrm{x}=2.5$ and $\mathrm{s}=0.9$ with 'high' (value 3 or $>$; thus of great importance or more) $=50.2 \%$. For 'time', the original question was: 'how many hours each week do you, on average, spend doing the following activities '? It was deemed necessary to record this time distribution in terms of proportion of the total time spent as a mayor rather than to focus on absolute numbers. For the item 'political party meetings', $\mathrm{x}=$ 5.4 and $s=4.6$ with 'high' (value 5.9 or $>$ ) $=42.7 \%$. For 'communication', the original question was 'how often do you normally communicate (orally) with the following persons/groups of persons'. Mayors could express the frequency of contact from 0 (seldom to never) to 4 (daily). For the item 'leaders of my own party' $\mathrm{x}=1.8$ and $\mathrm{s}=1.0$ with 'high' (value 2 or $>$; thus at least weekly) $=55.9 \%$. For 'participation', the original question was 'how much do you agree or disagree with the following statements'. Mayors could express agreement from 1 (strongly disagree) to 5 (strongly agree). For the item 'political parties are the most suitable arena for citizen participation', $\mathrm{x}=3.3$ and $\mathrm{s}=1.0$ with 'high' (value 4 or $>$; thus at least agree) $=52.5 \%$.

${ }^{23}$ The partisan recruitment variables refer to the following. Member (experienced) is based on the total number of years experienced as a party member at the election of 2000 . This variable $(\mathrm{x}=25.2$ and $\mathrm{s}=10.6)$ was dichotomized in terms of experience based on mayors that had 30 years of party experience or more $(42.9 \%)$. Party function refers to having held a party function before becoming mayor, which was the case for $51.6 \%$ of all respondents. Partisan support refers to a scale score ranging from 0 to 20 with $\mathrm{x}=8.3$ and $\mathrm{s}=4.3$. This scale was based on correlating items on the original question 'to what extent did you have the support of the following persons/groups of people in the last local election'. Mayors could answer from 0 (not at all) to 5 (to a very great extent). Factor analysis showed a partisan dimension $(51.3 \%$ of the variance explained) from the items 'the national organs of your party', 'your party wing/faction', 'your party at the local level', 'national politicians' and 'unions' that produced a reliable scale (Cronbach's alfa $=.75$ ). The scale was dichotomized for mayors having extensive (score 10 or >; or $37.9 \%$ of all respondents) party support or not. For context variables, $80.3 \%$ of mayors were elected on a national list and $55.9 \%$ in Flanders. 


\section{References}

Ackaert, J. (1996) 'De kiezers delen de kaarten uit, de partijen spelen ermee', In: Buelens, J. \& Deschouwer, K. (eds.) De dorpsstraat is de wetstraat niet, pp. 50-74 (Brussel: VUBPRESS).

Ackaert, J. (2005) 'The Transformation of the Political Executive in Belgian Local Government', In: Berg, R. \& Rao, N. (eds.) Transforming Political Leadership in Local Government, pp. 168-179 (Houndmills: Palgrave).

Bäck, H. (2006) 'Does Recruitment Matter? Selecting Path and Role Definition', In: Bäck, H., Heinelt, H. \& Magnier, A. (eds.) The European Mayor. Political Leaders in the Changing Context of Local Democracy, pp. 123-150. (Wiesbaden: VS Verlag).

Bäck, H., Heinelt, H. \& Magnie, A. (eds.) (2006) The European Mayor. Political Leaders in the Changing Context of Local Democracy (Wiesbaden: VS Verlag).

Balme, R. (1986) 'Councillors, Issue Agendas and Political Action in Two French Towns', In: Mabileau, A., Moyser, G., Parry, G. \& Quantin, P. (eds.) Local Politics and Participation in Britain and France, pp. 135-156 (Cambridge: Cambridge University Press).

Brady, H., Schlozman, K. \& Verba, S. (1999) Prospecting for Participants. Rational Expectations and the Recruitment of Political Activists, American Political Science Review 93(1), pp. 153-168.

Brand, J. (1972) Party Organization and the Recruitment of Councillors, British Journal of Political Science, 2(4), pp. 472-486.

Buelens, J. (1996) 'Over lijsten, namen en macht verwerven', In: Buelens, J. \& Deschouwer, K. (eds.) De dorpsstraat is de wetstraat niet, pp. 39-49 (Brussel: VUBPRESS).

Buelens, J., Rihoux, B. \& Deschouwer, K. (eds.) (2008) Tussen kiezer en hoofdkwartier. De lokale partijafdelingen en de gemeenteraadsverkiezingen van 2006 (Brussel: VUBPRESS).

Copus, C. (2004) Party Politics and Local Government (Manchester: MUP).

Dalton, R. \& Wattenberg, M. (eds.) (2002) Parties Without Partisans. Political Change in Advanced Industrial Democracies (Oxford: Oxford University Press).

Deschouwer, K. (1996) 'Nationale partijen en gemeenteraadsverkiezingen', In: Buelens, J. \& Deschouwer, K. (eds.) De dorpsstraat is de Wetstraat niet, pp. 13-26 (Brussel: VUBPRESS).

Devos, C., Matthyssen, E., Reynaert, H. \& Van Hoe, J. (1997) Hoe komen toekomstige mandatarissen in contact met de lokale politiek?, Res Publica, 39(1), pp. 63-88.

Dewachter, W. (1994) 'Gestalten van gemeenteraadsverkiezingen en de samenvoeging der gemeenten', In: Gemeentekrediet (eds) De gemeenteraadsverkiezingen en bun impact op de Belgische politiek, (1890-1970), pp. 465-490 (Brussel: Gemeentekrediet).

Edinger, L. \& Searing, D. (1967) Social Background in Elite Analysis: a Methodological Inquiry, American Political Science Review, 61(2), pp. 428-445.

Fallend, F., Ignits, G. \& Swianiewiczs, P. (2006) 'Divided Loyalties. Mayors between Party Representation and Local Community Interests', In: Bäck, H., Heinelt, H. \& Magnier, A. (eds.) The European Mayor. Political Leaders in the Changing Context of Local Democracy, pp. 245270 (Wiesbaden: VS Verlag).

Fiellin, A. (1969) Recruitment and Legislative Role Perceptions: A Conceptual Scheme and a Case Study, Western Political Quarterly, 20(2), pp. 271-287.

Gallagher, M. \& Marsh, M. (eds.) (1988) The Secret Garden of Politics. Candidate Selection in Comparative Perspective (London: Sage Publications).

Garraud, P. (1992) 'La ville en héritage. Hérédité familiale et héritage politique chez les maires urbains', In: Patriat, C. \& Parodi, J. (eds.) L'Hérédité politique, pp. 219-234 (Paris: Economica).

Garraud, P. (1989) Profession: homme politique. La carrière politique des maires urbains (Paris: L'Harmattan). 
Hain, P. (1974) Age, Ambition and Political Careers, Western Political Quarterly, 27(2), pp. 265275.

Hoffmann-Martinot, V. (1998) 'Urban Political Parties. The Role and Transformation', In: Clarck, T. \& Hoffmann-Martinot, V. (eds.) The New Political Culture, pp. 123-145 (Boulder: Westview Press).

Hunt, L. \& Pendley, R. (1972) Community Gatekeepers: an Examination of Political Recruiters, Midwest Journal of Political Science, 16(3), pp. 411-438.

Irwin, G. (1976) 'Party, Accountability and the Recruitment of Municipal Councilmen in the Netherlands', In: Eulau, H. \& Czudnowski, M. (eds.) Elite Recruitment in Democratic Polities, pp. 163-204 (New York: Sage).

Katz, R. \& Mair, P. (1995) Changing Models of Party Organisation and Party Democracy, Party Politics, 1(1), pp. 5-28.

Kjaer, U. (2006) 'The Mayor's Political Career', In: Bäck, H., Heinelt, H. \& Magnier, A. (eds.)

The European Mayor. Political Leaders in the Changing Context of Local Democracy, pp. 75-98 (Wiesbaden: VS Verlag).

Lecomte, P. (1989) Comment viennent-ils à la politique? L'engagement des nouvelles recrues du RPR, Revue Française de Science Politique, 39(2), pp. 683-697.

Luther, K.-R. \& Müller-Rommel, F. (eds.) (2005) Political Parties in the New Europe (Oxford: Oxford University Press).

Moss, L. \& Parker, S. (1967) Management of Local Government. Volume 2. The Local Government Councillor (London: Her Majesty's Stationary Office).

Mouritzen, P. \& Svara, J. (2002) Leadership at the Apex. Politicians and Administrators in Western Local Governments (Pitssburg: Pitssburg University Press).

Norris, P. (1997) 'Theories of Recruitment', In: Norris, P. (ed.) Passages to Power. Legislative Recruitment in Advanced Democracies, pp. 1-14 (Cambridge: Cambridge University Press).

Offerdal, A. (2003) 'Whose Mayor? Representational Roles in Local Politics', In: Baldersheim, H., Illner, M. \& Wollmann, H. (eds.) Local Democracy in Post-Communist Europe, pp. 273-88. (Leske + Budrich: Opladen).

Prewitt, K. (1970) The Recruitment of Political Leaders. A Study of Citizen-Politicians (Indianapolis: Bobbs-Merill Company Inc.).

Rao, N. (ed) (2000) Representation and Community in Western Democracies (Houndmills: MacMillan Press Ltd.)

Sartori, G. (1976) Parties and Party Systems. A Framework for Analysis. (Cambridge: Cambridge University Press).

Schlesinger, J. (1966) Ambition and Politics. Political Careers in the United States. (Chicago: Rand McNally).

Seligman, L. (1961) Party Structure and Political Recruitment, American Political Science Review 55(1), pp. 77-86.

Seligman, L. (1971) Recruiting Political Elites (Glencoe: General Learning Press).

Steyvers, K. (2004) Van burger tot burgervader. Het politieke rekruteringsproces van de Belgische burgemeester (Brugge: Vanden Broele).

Steyvers, K. (2007) 'Wat is lokale politiek?', In: Reynaert, H. (ed.) De Kerktorenpolitiek voorbij? Lokale politiek in Vlaanderen, pp. 17-40 (Brugge: Vanden Broele).

Steyvers, K. \& Reynaert, H. (2005) Een noord-zuid kloof in de lokale politiek? Een vergelijking tussen de Vlaamse en de Waalse burgemeester, Burger, Bestuur \& Beleid, 1(3), pp. 223-241.

Steyvers, K. \& Reynaert, H. (2006) "From the Few are Chosen the Few". On the Social Background of the European Mayor', In: Bäck, H., Heinelt, H. \& Magnier, A. (eds.) The European Mayor. Political Leaders in the Changing Context of Local Democracy, pp. 43-74. (Wiesbaden: VS Verlag). 
Steyvers, K. \& Reynaert, H. (2006) 'Van kartel tot cordon: de inzet van de gemeenteraadsverkiezingen 2006', In: Reynaert, H. (ed.) Naar een versterkte lokale en provinciale democratie, pp. 1-37 (Brugge: Vanden Broele).

Steyvers, K., Reynaert, H., De Ceuninck, K. \& Valcke, T. (2006) Mayors in Governance: Heading for Efficiency and Democracy. The Belgian Case, Local Government Studies, 32(4), pp. 1-18.

Steyvers, K., Reynaert, H., De Ceuninck, K. \& Valcke, T. (2008) 'All Politics is Local, Partisan or National? Local Lists in Belgium', In: Holtman, E. \& Reiser, M. (eds.) Farewell to the Party Model? Independent Local Lists in East and West European Countries, pp. 169-94. (Wiesbaden: VS Verlag).

Thurber, J. (1976) The Impact of Party Recruitment Activity upon Legislative Role Orientations: A Path Analysis, Legislative Studies Quarterly, 1(4), pp. 533-550.

Van Liefferinge, H. \& Steyvers, K. (2009) Family Matters? Degrees of Family Politicization in Political Recruitment and Career Start of Mayors in Belgium, Acta Politica, 44(2), pp. 125149.

Ware, A. (1996) Political parties and party systems (Oxford: Oxford University Press). 